\title{
Experience in Monitoring Gentamicin Therapy During Treatment of Serious Gram-Negative Sepsis
}

\author{
P. NOONE, T. M. C. PARSONS, J. R. PATTISON, \\ K. HUGHES \\ R. C. B. SLACK, \\ D. GARFIELD-DAVIES,
}

British Medical fournal, 1974, 1, 477-481

\begin{abstract}
Summary
This paper reports our experience in monitoring gentamicin therapy during the treatment of 68 episodes of serious Gramnegative sepsis in 65 hospital patients. Most of the patients had major underlying disease. Of those who were adequately treated (peak serum concentrations of $5 \mu \mathrm{g} / \mathrm{ml}$ or more in 72 hours for septicaemia, urinary tract infection, and wound infection; and $8 \mu \mathrm{g} / \mathrm{ml}$ or more at some time during the course of treatment for pneumonia) $84 \%$ (46 out of 55) were cured. These serum concentrations could be achieved only by starting with a regimen of $5 \mathrm{mg} / \mathrm{kg} /$ day in three divided doses in all adult patients, subsequent dosage being determined by the results of rapid serum assay. The incidence of nephrotoxicity and symptomatic ototoxicity was no greater than in previous series. The main reason for assaying serum gentamicin is to ensure that an adequate dosage is achieved as soon as possible. In patients with impaired renal function or receiving prolonged high dosage assays also serve to guard against an excessive accumulation of gentamicin and an increased risk of toxicity.
\end{abstract}

\section{Introduction}

Gentamicin is widely considered to be the first-choice antibiotic for serious Gram-negative sepsis (Martin et al., 1969; Marsden and Hyde, 1970; Darrell and Neale, 1972). Its use has been associated with otutoxicity in 2 to $3 \%$ of patients (Jackson and Arcieri, 1971), while nephrotoxicity has also been reported (Hewitt, 1971; Wilfert et al., 1971). At first toxicity was thought to be related to serum concentration and therefore monitoring gentamicin therapy was considered essential, especially in patients with impaired renal funotion or undergoing dialysis. Rapid assay techniques now permit close monitoring of aminoglycoside therapy, allowing doseby-dose modification. We repont an analysis of our experience treating 68 episodes of serious Gram-negative infection among 65 hospital patients, including a retrospective assessment of 8 th cranial nerve function in 23 patients.

\footnotetext{
Department of Bacteriology, School of Pathology, Middlesex Hospital Medical School, London W1P 7LD

P. NOONE, B.M., M.R.C.PATH., Lecturer (Present appointment: Consultant Bacteriologist, Department of Medical Microbiology, The Royal Free Hospital, London WC1X 8LF)

T. M. C. PARSONS, M.B., M.R.C.P., Assistant Lecturer

T. M. C. PARSONS, M.B., M.R.C.P., Ass

J. R. PATTISON, B.M., B.CH., Lecturer
R. C. B. SLACK, M.B., B.CH., Assistant Lecturer

Ferens Institute of Otolaryngology, Middlesex Hospital Annexe, London W1P 5FD

D. GARFIELD-DAVIES, M.B., F.R.C.s., Consultant Surgeon

K. HUGHES, M.B., F.R.C.S., Registrar
}

\author{
Materials and Methods \\ BACTERIOLOGICAL INVESTIGATIONS
}

Urine cultures were performed at $37^{\circ} \mathrm{C}$ on C.L.E.D. agar (Oxoid Limited) using a standard loop technique. Blood specimens were taken into tryptose soya broth (Oxoid) for aerobic culture and Brewer's thioglycollate medium (Oxoid) for anaerobic culture at $37^{\circ} \mathrm{C}$. Sputum was digested with trypure-pancreatin mixture and cultured at $37^{\circ} \mathrm{C}$ on Columbia blood agar (Oxoid) and MacConkey agar (Oxoid) at dilutions of $1 / 2$ and $1 / 10^{-4}$ (diluted in quarter-strength Ringer's solution). Wound swabs, aspirations of pus, and pleural fluid were cultured at $37^{\circ} \mathrm{C}$ aerobically and anaerobically (in hydrogen with $5 \%$ carbon dioxide) on Columbia agar and MacConkey agar. Organisms isolated by these methods were identified according to the criteria and techniques recommended by Cowan and Steel (1966). Antibiotic sensitivity tests for Gram-negative organisms were performed at $37^{\circ} \mathrm{C}$ on D.S.T. agar (Oxoid) with $10 \%$ lysed horse blood using Oxoid antibiotics disks. Eschericia coli (N.C.T.C. 10418) and Pseudomonas aeruginosa (N.C.T.C. 10662) were used daily as controls. All Gram-negative isolates were sensitive to gentamicin by this method. The minimum inhibitory concentration of particular antibiotics was determined according to the methods described by Cruickshank (1965).

\section{BASIS OF MONITORING THERAPY}

The advice on therapy given by medical microbiologists was based on the following observations. Pharmacological studies in man indicate that "the concentration of gentamicin in the blood is representative of the tissue level throughout the body and this value may be used for therapeutic purposes" (Chisholm et al., 1968). Peak serum concentrations after intramuscular injection occur within 30-120 minutes, but the concentration in serum taken one hour after the injection is at least $70 \%$ of the peak concentration after any single dose (Black et al., 1963). In-vitro studies showed that the minimum inhibitory concentration of gentamicin for all the aerobic Gram-negative isolates from clinically-significant sepsis was 2 $\mu \mathrm{g} / \mathrm{ml}$ or less. At first, therefore, adequate gentamicin therapy was considered to be that dosage which gave a serum concentration of at least $5 \mu \mathrm{g} / \mathrm{ml}$ one hour after an intramuscular injection or 15 minutes after an intravenous injection of the antibiotic (hereafter referred to as peak concentration). In the treatment of serious or life-threatening sepsis it seemed logical to try to achieve such concentrations as early as possible in a course of gentamicin. The urease method (Noone et al., 1972) was used to assay gentamicin throughout this study. A noticeable individual variation in the peak serum concentrations in response to a dose of $1 \mathrm{mg} / \mathrm{kg} /$ day in three divided doses, irrespective of blood urea concentration, was quickly apparent. About $30 \%$ of patients did not achieve serum concentrations above $3 \mu \mathrm{g} / \mathrm{ml}$ on such regimens. Therefore the concept of a fixed dosage adequate in all patients was abandoned and dose regimens were adjusted according to serum concentrations. Where gentamicin might accumulate (because of renal failure or prolonged high 
dosage) monitoring included measuring residual gentamicin ("trough" concentration) in sera taken just before the next dose was given.

\section{OTOLOGICAL STUDIES}

Most patients were too ill for any studies of eighth cranial nerve function before being given gentamicin. Of 40 patients who survived their infection and whose underlying condition sufficiently improved 23 agreed to detailed vestibular and audiometric investigations. Eleven of the 23 had standard Hallpike caloric tests and pure tone audiograms. Békèsy audiometry was carried out on 12 patients, and an electronystagmograph was used to record spontaneous nystagmus with eyes open and fixating, eyes open in darkness, eyes closed, and during positional testing and the standard Hallpike caloric tests.

\section{Results}

\section{URINARY TRACT INFECTIONS}

In 20 episodes of urinary tract infections (table I) treatment with gentamicin was made necessary by the limited range of sensitivities of the infecting organisms to the antibiotics tested. Those in all six infections due to Klebsiella species were sensitive only to gentamicin, tetracycline, and polymyxin, while four of the isolates of Ps. aeruginosa were resistant to carbenicillin. Other antibiotics to which the infecting organism was sensitive were given in four cases (three cures and one fail- ure). Check urine cultures taken not less than 48 hours after the end of antibiotic treatment were examined and further detailed follow-up was available for between four days and six months (mean two months). A peak serum concentration of 5 $\mu \mathrm{g} / \mathrm{ml}$ was achieved in the first three days of treatment in all the 17 episodes $(85 \%)$ that were cured. In only one of the three failures was similar adequate therapy achieved, whereas in the other two serum concentrations of $5 \mu \mathrm{g} / \mathrm{ml}$ or more were not achieved until the tenth day of treatment. In one the minimum inhibitory concentration of gentamicin for the infecting Ps. aeruginosa had risen during this time from $0.6 \mu \mathrm{g} /$ $\mathrm{ml}$ to more than $40 \mu \mathrm{g} / \mathrm{ml}$. The other patient died of the complications of a Proteus mirabilis urinary tract infection; necropsy showed peritonitis, subphrenic and pelvic abscesses, and severe bilateral acute pyelonephritis.

\section{WOUND INFECTION}

The criteria for diagnosis in the 15 episodes of wound infection (table II) were inflammation, drainage of pus, and isolation of pathogenic bacteria. In all but three cases gentamicin was the only chemotherapeutic agent to which the organisms were sensitive. Twelve ( $75 \%$ ) were cured of infection though six patients died later of their underlying malignancy. In all 15 episodes a peak serum concentration of $5 \mu \mathrm{g} / \mathrm{ml}$ or more was achieved during the course of gentamicin, but there was no apparent correlation between the outoome and how soon the peak was reached. The clinical condition of the patient in this group appears to be much more significant. All three patients who died with infection as a major contributory fac-

TABLE I-Clinical Details of 20 Episodes of Urinary Tract Infection Treated with Gentamicin

\begin{tabular}{|c|c|c|c|c|c|c|c|}
\hline \multirow{3}{*}{$\frac{\text { Outcome }}{\text { Cure }}$} & \multirow{3}{*}{$\begin{array}{c}\begin{array}{c}\text { Total } \\
\text { No. } \\
\text { of Episodes }\end{array} \\
17\end{array}$} & \multicolumn{2}{|c|}{ Patients $(n=19)$} & \multirow{3}{*}{$\begin{array}{l}\text { Organism } \\
\text { (No. of Episodes of Infection) }\end{array}$} & \multirow{2}{*}{\multicolumn{2}{|c|}{$\begin{array}{l}\text { Relevant Underlying Conditions } \\
\text { (No. of Cases) }\end{array}$}} & \multirow{3}{*}{ 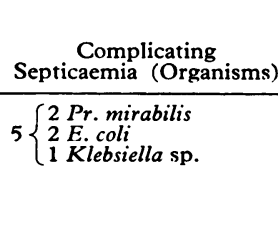 } \\
\hline & & \multirow{2}{*}{$\begin{array}{l}\text { Age (Years) } \\
47-84 \\
\text { (mean 64) }\end{array}$} & \multirow{2}{*}{$\frac{\text { Sex }}{10 \mathrm{M} ., 7 \mathrm{~F} .}$} & & & & \\
\hline & & & & & $\begin{array}{l}\text { Catheterization } \\
\text { Urinary tract surgery } \\
\text { Chronic renal failure } \\
\text { Anatomical abnormalities of } \\
\text { urinary tract } \\
\text { Malignant neoplasms }\end{array}$ & $\begin{array}{l}(9) \\
(6) \\
(2) \\
(1) \\
(4)\end{array}$ & \\
\hline Failure & 3 & $\begin{array}{l}7 \text { weeks, } \\
51,69\end{array}$ & 2 M., 1 F. & $\begin{array}{l}\text { Ps. aeruginosa (2) } \\
\text { Pr. mirabilis (1) }\end{array}$ & $\begin{array}{l}\text { Catheterization } \\
\text { Chronic renal failure } \\
\text { Anatomical abnormalities of } \\
\text { urinary tract } \\
\text { Malignant neoplasms }\end{array}$ & $\begin{array}{l}(2) \\
(1) \\
(1) \\
(2)\end{array}$ & 1 (Pr. mirubilis) \\
\hline
\end{tabular}

TABLE II-Clinical Details of 15 Episodes of Wound Infection Treated with Gentamicin

\begin{tabular}{|c|c|c|c|c|c|c|c|c|c|}
\hline \multirow{2}{*}{ Outcome } & \multirow{2}{*}{$\begin{array}{l}\text { Total No. of } \\
\text { Episodes }\end{array}$} & \multicolumn{2}{|c|}{ Patients $(\mathrm{n}=15)$} & \multirow{2}{*}{$\begin{array}{l}\text { Site of Operation } \\
\text { (No. of Cases) }\end{array}$} & \multirow{2}{*}{\multicolumn{2}{|c|}{$\begin{array}{l}\text { Complications } \\
\text { (No. of Cases) }\end{array}$}} & \multirow{2}{*}{$\begin{array}{l}\text { Malignant } \\
\text { Neoplasms }\end{array}$} & \multirow{2}{*}{\multicolumn{2}{|c|}{$\begin{array}{l}\text { Organism (No. } \\
\text { of Episodes of Infection) }\end{array}$}} \\
\hline & & $\overline{\text { Age (Years) }}$ & Sex & & & & & & \\
\hline Cure & 12 & $\begin{array}{l}20-69 \\
\text { (mean 54) }\end{array}$ & 7 M., 5 F. & $\begin{array}{ll}\text { Bowel } & (6) \\
\text { Hip } & (3) \\
\text { Larynx } & (2) \\
\text { Uterus } & (1)\end{array}$ & $\begin{array}{l}\text { Faecal peritonitis } \\
\text { Abscess } \\
\text { Septicaemia ( } 2 \text { confirmed, } \\
\quad 2 \text { suspected })\end{array}$ & $\begin{array}{l}(2) \\
(4) \\
(4)\end{array}$ & 5 & $\begin{array}{l}\text { Ps. aeruginosa } \\
\text { E. coli } \\
\text { Atypical E. coli } \\
\text { Proteus sp. } \\
\text { Klebsiella sp. }\end{array}$ & $\begin{array}{r}(7 ; 3 \text { mixed }) \\
(5 ; 2 \text { mixed }) \\
(1 \text { mixed }) \\
(2 \text { mixed }) \\
(2 \text { mixed })\end{array}$ \\
\hline Failure & 3 & $68,64,34$ & 2 F., 1 M. & $\begin{array}{l}\text { Bowel (2) } \\
\text { Gall Bladder (1) }\end{array}$ & $\begin{array}{l}\text { Faecal peritonitis } \\
\text { Abscess }\end{array}$ & (2) & 1 & $\begin{array}{l}\text { E. coli } \\
\text { Atypical E. coli } \\
\text { Froteus sp. }\end{array}$ & $\begin{array}{c}\text { (2) } \\
\text { (1 mixed) } \\
\text { (1 mixed) }\end{array}$ \\
\hline
\end{tabular}

TABLE III-Clinical Details of 29 Episodes of Gram-negative Pneumonia Treated with Gentamicin

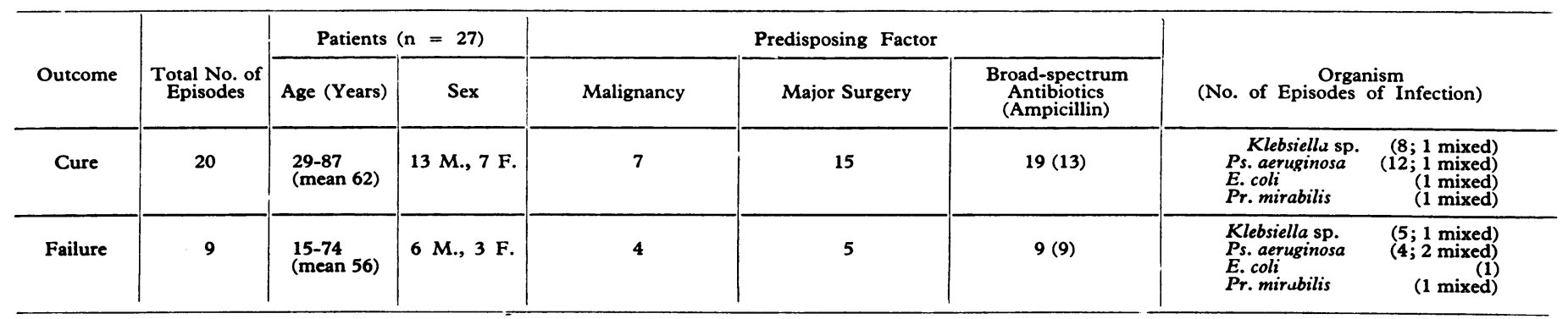


tor had evidence of deep tissue involvement. Of five patients with abscesses four were drained and were cured and one was not drained and died. Of four patients with peritonitis the two aged 60 years or over with neoplastic or necrotic areas of bowel died and the two who survived were aged 34 and 20 years and had benign disease of the bowel. Nevertheless, these latter patients were also noteworthy because of the very high serum concentrations of gentamicin achieved. One with confirmed $E$. coli septicaemia had peak serum concentrations of between 12 and $18 \mu \mathrm{g} / \mathrm{ml}$ on each of the first five days of treatment. The other, through renal insufficiency coincident with the course of gentamicin, had peak serum concentrations of 12 to $30 \mu \mathrm{g} / \mathrm{ml}$ and trough concentrations of up to 15 $\mu \mathrm{g} / \mathrm{ml}$. No evidence of toxicity was seen in either patient.

\section{GRAM-NEGATIVE PNEUMONIA}

All 29 episodes of pneumonia (table III) were characterized by the association of clinical signs and symptoms (pyrexia, purulent sputum production, dyspnoea, and chest pain) with radiological signs of pneumonia. Gram-negative organisms were considered to be the causative pathogens since they were isolated in heavy growth (that is, more than $10^{4}$ organisms $/ \mathrm{ml}$ ) by dilution technique from fresh sputum aspirated from the lower respiratory tract (11 cases), or from two (three cases) or more than two (13 cases) freshly-taken purulent specimens of sputum. In 25 episodes a single organism was isolated in pure growth and in four a mixture of two Gram-negative organisms was found. The same organisms were also isolated from blood cultures (three cases), pleural aspirate (three cases), and swabs of lung pus taken at necropsy (one case). Since 24 of the episodes of pneumonia occurred during or immediately after the administration of ampicillin (and of cloxacillin also in 12) it is most unlikely that the clinical signs and symptoms were due to Haemophilus species or Streptococcus pneumoniae, the isolation of which was masked by overgrowth with "contaminating" coliforms or Pseudomonas. Moreover, 11 of the 12 episodes treated with gentamicin alone were cured, whereas of the 16 episodes treated with gentamicin in combination with other antimicrobial drugs (carbenicillin in three, ampicillin in two, ampicillin and cloxacillin in six, cephalosporin in four, and benzylpenicillin in one) only eight were cured. Nevertheless, both patients who received adequate doses of antibiotics other than gentamicin to which the isolated Gram-negative organisms were known to be sensitive were cured. Thus there is very good direct and indirect evidence of the aetiological nature of the Gram-negative isolates in these cases of pneumonia. In those cured the patients were alive and well six months to two years later except one who died of an unrelated cerebrovascular accident six months later.

There is no significant difference between the episodes of cured and uncured pneumonia in terms of age, underlying disease, or organisms isolated. Nevertheless, the monitoring of serum gentamicin concentrations in these cases indicated that a peak serum concentration of $8 \mu \mathrm{g} / \mathrm{ml}$ (rather than the anticipated $5 \mu \mathrm{g} / \mathrm{ml}$ ) or more was significant. In two patients assays were not done and in two others with irreversible brain damage the courses were discontinued. Peak serum concentrations of $8 \mu \mathrm{g} / \mathrm{ml}$ or more were achieved during the treatment of 18 of the remaining 25 episodes of pneumonia, and of these 16 $(89 \%)$ were cured. In one case the patient died after seven days treatment, a concentration of $8 \mu \mathrm{g} / \mathrm{ml}$ or greater having been achieved only on the last day, and in another the patient was discharged clinically improved but with her sputum still positive for the organism originally isolated. Of the seven episodes in which a peak serum concentration of $8 \mu \mathrm{g} / \mathrm{ml}$ or more was not achieved only three $(43 \%)$ were cured. In two of these only a single assay was done, giving values of 5.0 and $7.0 \mu \mathrm{g} / \mathrm{ml}$ respectively, and in the third three were three peak values between 5.5 and $7.0 \mu \mathrm{g} / \mathrm{ml}$. In three cases clinical improvement took place only when the dose was increased on the basis of results of assays, and in one case on low dose therapy improvement occurred only when acute renal failure supervened and high serum concentrations developed.

\section{GRAM-NEGATIVE SEPTICAEMIA}

A clinical diagnosis of Gram-negative septicaemia was confirmed in 15 episodes of infection by growing the same organism from at least two blood cultures (in one case from the transfusion pack). Eleven out of the 15 episodes were associated with the episodes of urinary tract infection, wound infection, or pneumonia reponted above. They were all treated with gentamicin (table IV).

This series followed the usual pattern for cases of Gramnegative septicaemia (Altemeier et al., 1967) in age distribution, prevalence of pathogens, and nature of underlying focus of infections (table IV). Gentamicin was the antibiotic of first choice before bacteriological results were available.

TABLE IV-Clinical Details of 15 Episodes of Gram-negative Septicaemia Treated with Gentamicin

\begin{tabular}{|c|c|c|c|c|c|c|}
\hline Outcome & Total No. of Episodes & $\begin{array}{c}\text { Age of Patients } \\
\text { (Years) }\end{array}$ & \multicolumn{2}{|c|}{ Organism (No. of Episodes) } & \multicolumn{2}{|c|}{ Focus of Infection (No. of Episodes) } \\
\hline Cure & 10 & $20-70$ (mean 57) & $\begin{array}{l}\text { E. coli } \\
\text { Klebsielia sp. } \\
\text { Pr. mirabilis } \\
\text { Ps. aeruginosa }\end{array}$ & $\begin{array}{l}(4) \\
(3) \\
(2) \\
(1)\end{array}$ & $\begin{array}{l}\text { Urinary tract } \\
\text { Bowel } \\
\text { Heart valve } \\
\text { Transfusion pack }\end{array}$ & $\begin{array}{r}(6) \\
(2) \\
(1 \text { each) }\end{array}$ \\
\hline Failure & 5 & $51-68($ mean 61$)$ & $\begin{array}{l}\text { E. coli. } \\
\text { Klebsiella sp. } \\
\text { Pr. mirabilis } \\
\text { Ps. aeruginosa } \\
\text { Cit.-ballerupensis }\end{array}$ & $\begin{array}{l}(1) \\
(1) \\
(1) \\
(1) \\
(1)\end{array}$ & $\begin{array}{l}\text { Respiratory tract } \\
\text { Urinary tract } \\
\text { Bowel } \\
\text { Biliary tract }\end{array}$ & $\begin{array}{r}(2) \\
(1 \text { each) }\end{array}$ \\
\hline
\end{tabular}

TABLE v-Overall Results in 68 Episodes of Gram-negative Sepsis Treated with Gentamicin

\begin{tabular}{|c|c|c|c|c|c|c|c|c|c|c|}
\hline \multirow{3}{*}{$\begin{array}{l}\text { No. of } \\
\text { Episodes of } \\
\text { Sepsis }\end{array}$} & \multicolumn{2}{|c|}{ Patients $(n=65)$} & \multirow{3}{*}{$\begin{array}{c}\text { With } \\
\text { Malignant } \\
\text { Neoplasms }\end{array}$} & \multirow{3}{*}{$\begin{array}{c}\text { After } \\
\text { Major } \\
\text { Surgery }\end{array}$} & \multicolumn{6}{|c|}{ Outcome } \\
\hline & \multirow[t]{2}{*}{$\begin{array}{l}\text { Aged } 60 \\
\text { Years } \\
\text { and Over }\end{array}$} & \multirow[t]{2}{*}{ Sex } & & & \multicolumn{2}{|c|}{ Overall } & \multicolumn{2}{|c|}{$\begin{array}{l}\text { Adequately } \\
\text { Treated } \\
(81 \% \text { of Total })\end{array}$} & \multicolumn{2}{|c|}{$\begin{array}{c}\text { Inadequately } \\
\text { Treated } \\
(19 \% \text { of Total })\end{array}$} \\
\hline & & & & & Cure & Failure ${ }^{+}$ & Cure & Failure & Cure & Failure \\
\hline 68 & $65 \%$ & $40 \mathrm{M} ., 25 \mathrm{~F}$. & $38^{\prime \prime}$ & $73 \%$ & $72 \%$ & $28 \%$ & $84 \%$ & $16 \%$ & $23 \%$ & $77 \%$ \\
\hline
\end{tabular}

*Peak serum concentrations of $5 \mu \mathrm{g} / \mathrm{ml}$ or more in 72 hours for septicaemia, urinary tract infection, and wound infection; and $8 \mu \mathrm{g} / \mathrm{ml}$ or more at some time during the course of treatment for pneumonia.

$+82 \%$ (14 out of 17) of these patients died with infection as a major contributory factor. 
In only two cases were the patients sufficiently improved clinically when the sensitivities of the infecting organism were known for gentamicin to be discontinued and therapy with ampicillin and co-trimoxazole substituted. Of the five patients treated with a combination of gentamicin and another antibiotic to which the infecting organism was also sensitive three survived and two died. Overall, 10 patients recovered and five died either directly from septicaemia or from other causes with septicaemia as a contributory factor. In all 10 patients who were cured of septicaemia a level of $5 \mu \mathrm{g} / \mathrm{ml}$ was recorded during the first three days of treatment. Of the five patients who died only one had such a level recorded in the first three days of treatment, three never achieved such a level, and one only on the tenth day of treatment.

\section{Side Effects}

\section{NEPHROTOXICITY}

Two of the five patients treated with a combination of gentamicin and a cephalosporin (cephaloridine in four and cephalothin in one case) developed acute renal failure during therapy. One had been treated with gentamicin and cephaloridine for two weeks when, after a period of relative dehydration after bronchoscopy under general anaesthesia, renal failure developed. Antibiotic therapy was stopped after a further four days and renal function improved satisfactorily in one month. The second patient developed renal failure and died during treatment with gentamicin and cephaloridine for a Pr. mirabilis urinary tract infection and septicaemia. In two patients the blood urea rose (from 43 to 73 and 45 to $171 \mathrm{mg}$ / $100 \mathrm{ml}$ respectively) during gentamicin therapy and fell when the drug was stopped. There was nothing remarkable about the duration of therapy, the dose, or the peak serum concentrations in these four patients.

\section{ототоXICITY}

None of the 23 patients tested complained of any increased hearing deficit after the administration of gentamicin, and audiometry showed no impairment of auditory function that was incompatible with the age group (48-74 years, mean 63 years). In only one case was vestibular function subjectively impaired, but there was a history of unsteadiness, bilateral Menière's disease, and left labyrinthectomy. Though the patient had a severe high tone sensorineural loss and no reaction on an electronystagmograph on the right side, it was impossible to tell whether the inner ear function had been affected by the gentamicin. Of the remaining 22 patients with no subjective loss of vestibular function three had a unilateral canal paresis and a fourth a unilateral loss of reaction to water at $30^{\circ} \mathrm{C}$ though reactions to water at $44^{\circ} \mathrm{C}$ were normal. In this small sample vestibular dysfunction could not be significantly correlated with age, total or daily dose of gentamicin, peak serum gentamicin concentration, or degree of impairment of renal function. None of the patients were known to have had ototoxic drugs previously.

\section{Discussion}

This series confirms certain facts about cases of serious Gramnegative sepsis (table V). The most striking predisposing factor, especially for pneumonia, seems to be previous treatment with broad-spectrum antibiotics, particularly ampicillin. Such antibiatics were most often given for non-specific broad spectrum prophylaxis in cases of major surgery, cardiac failure, respiratory distress, radiotherapy, etc. This practice is of very doubtful benefit, and perhaps Gram-negative pneumonia and sepsis generally may be better prevented by withholding antibiotics except when specifically indicated (Price and Sleigh, 1970).

Gentamicin is of proved value in urinary tract infections. Concentrations of the drug in the urine are about 5 to 10 times the peak serum concentrations (Riff and Jackson, 1971). Attention to high serum concentrations may not be considered necessary. Nevertheless, in this series two of the "failures" exemplify two dangers of underdosage-emergence of antibiotic resistance in the infecting organism, and failure of therapy leading to complications and death of the patient. Of the 18 episodes in which a peak serum concentration of 5 $\mu \mathrm{g} / \mathrm{ml}$ or greater was achieved in the first three days of treatment the cure rate was $94 \%$. The efficacy of systemicallyadministered gentamicin in the treatment of Gram-negative pneumonia has been much less centain. For example. Gatmaitan et al. (1970) reported favourable results, whereas Klastersky et al. (1972) reported only two cures in eight cases treated with systemic gentamicin. Nevertheless, in the present series, where strict criteria were used for determining diagnosis and cure, a cure rate of $89 \%$ was achieved in 18 patients in whom peak serum concentrations of $8 \mu \mathrm{g} / \mathrm{ml}$ or more were obtained. Possibly the relatively poor penetration of the drug into infected lung tissue explains the need for higher peak serum concentrations in patients with pneumonia. Ten out of $11(90 \%)$ of the patients with episodes of Gram-negative septicaemia in whom peak serum concentrations of $5 \mu \mathrm{g} / \mathrm{ml}$ or more were achieved within the first three days of treatment were cured. With wound infections the outcome was closely related to complications and the general condition of the patient, but notably two young patients who recovered completely from faecal peritonitis and Gramnegative shock had consistently the highest serum concentrations recorded in all 65 patients.

The overall cure rate in adequately treated patients was $84 \%$ (table V). Larger daily doses than those conventionally recommended are necessary for adequate therapy. In adults $5 \mathrm{mg} / \mathrm{kg} /$ day in three divided doses is the minimum starting treatment regardless of renal function. Serum concentrations should be monitored to ensure adequate therapy, and subsequent dosage, depending on individual response, may have to be reduced in patients with impaired renal function or increased even funther in patients with a "damped response" (Riff and Jackson, 1971). Patients with normal renal function or a stable impairment of renal function usually stabilize easily, but patients with acutely impaired renal function need particularly close monitoring. The unpredictability of an individual patient's response to gentamicin makes it virtually impossible to achieve adequate therapy by regulating dosage according to blood urea, serum creatinine, or creatinine clearance estimations. In the first critical 72 hours of life-threatening Gram-negative infection the easiest and most direct way of ensuring adequate therapy is to measure peak serum concentrations. The duration of treatment depends on the clinical response, but seems to be about 7 to 10 days. In this series we found no evidence that other antibiotics should be given in combination with gentamicin.

Obviously, increased doses are acceptable only if they do not noticeably increase the incidence of toxicity. Evidence that gentamicin alone was nephrotoxic was insubstantial, but of five patients treated with combined gentamicin and cephalosporin two developed acute renal failure. This combination is now well-recognized as potentially nephrotoxic. (Noone et al., 1973). In our experience cephalosporin adds nothing to the effectiveness of adequate gentamicin therapy in Gram-negative infections.

Symptomatic atotoxicity was not seen. Detailed investigation of eighth cranial nerve funotion showed abnormalities of vestibular function probably related to gentamicin therapy 
in $4(18 \%)$ out of 22 patients. Though this did not cause symptoms it nevertheless emphasizes the need to avoid giving gentamicin for minor sepsis. But in life-threatening Gramnegative sepsis in hospital practice we believe gentamicin therapy is the treatment of choice. There is still a tendency to give inadequate doses of gentamicin because of excessive anxiety about its toxicity. Inadequately-treated serious Gramnegative sepsis has a high mortality. The present series shows that vigorous but closely monitored gentamicin therapy gives excellent results without significant toxicity.

We therefore recommend that peak serum concentrations should be measured from the first day of treatment and the dose modified accordingly until values of at least $5 \mu \mathrm{g} / \mathrm{ml}$ or preferably $8-12 \mu \mathrm{g} / \mathrm{ml}$ are achieved. Dosage should be reduced only if concentrations exceed $15 \mu \mathrm{g} / \mathrm{ml}$. Further assays of peak concentrations should be made when the dosage is altered. Trough concentrations as well as peaks should also be measured when there is a change in renal function and at least twice weekly during prolonged therapy. Closer monitoring is necessary during renal dialysis or the oliguric/anuric phase of acute renal failure. The more important function of monitoring is to ensure that adequate peak serum concentrations are reached as soon as possible, provided there is no severe renal dysfunction.

\section{References}

Altermeier, W. A., Todd, J. C., and Inge, W. W. (1967). Annals of Surgery, $166,530$.

Black, J., Calesnick, B., Williams, D., and Weinstein, M. J. (1963). Antimicrobial Agents and Chemotherapy, 3, 138.

Chisholm, G:" D., Calnan, J. S., and Waterworth, Patricia M. (1968). Urinary Tract Infection. Proceedings of 1st National Symposium, ed. F. O'Grady and W. Brumfitt, p. 208. London, Oxford University Press.

Cowan, S. T., and Steel, K. J. (1966). Manual for the Identification of Medical Bacteria. London, Cambridge University Press.

Cruickshank, R. (1965). Medical Microbiology, 11th edn. Edinburgh, $\mathrm{E}$. and S. Livingstone.

Darrell, J. H., and Neale, G. (1972). Prescriber's fournal, 12, 51.

Gatmaitan, B. G., Carruthers, M. M., and Lerner, A. M. (1970). American Fournal of Medical Science, 260 , 90.

Hewitt, W. L. (1971). Fournal of Infectious Diseases, 124, 154.

Jackson, G. G., and Arcieri, G. (1971). Fournal of Infectious Diseases, 124,

S. 130.
Klastersky, J., Genning, C., Monawad, E., and Daneau, D. (1972). Chest,

Marsden, H. B., and Hyde, W. A. (1970). Current Therapeutic Research,

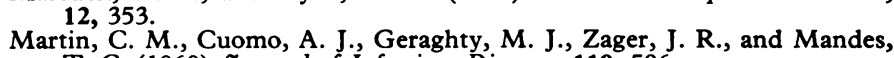
T. C. (1969). Fournal of Infectious Diseases, 119, 506.

Noone, P., Pattison, J. R., and Shafi, M. S. (1973). British Medical fournal, 2, 776 .

Noone, P., Pattison, J. R., and Slack, R. C. B. (1972). Lancet, 2, 1194.

Price, D. J., and Sleigh, J. D. (1970). Lancet, 2, 1213.

Riff, Louise J., and Jackson, G. G. (1971). Fournal of Infectious Diseases, 124, S. 98 .

Wilfert, J. N., Burke, J. P., Bloomer, H. A., and Smith, C. B. (1971). Fournal of Infectious Diseases, 124, S. 148.

\title{
Salt-poor Human Albumin in Management of Nephrotic Syndrome
}

\author{
A. M. DAVISON, A. T. LAMBIE, A. H. VERTH, J. D. CASH
}

British Medical fournal, 1974, 1, 481-484

\section{Summary}

Thirteen patients with the nephrotic syndrome were treated with a high-protein diet, a $0.5 \mathrm{~g}$ sodium intake (equivalent to $1.3 \mathrm{~g}$ sodium chloride), and frusemide in increasing dosage. One became oedema-free with frusemide $240 \mathrm{mg}$ daily, three became oedema-free with frusemide $500 \mathrm{mg}$ daily, and two required a combination of high-dose frusemide and spironolactone. In three there was an appreciable increase in the blood urea, one patient developed hyponatraemia, and in two there was no weight loss. In these six patients infusions of human salt-poor albumin produced a prompt diuresis, loss of weight, and correction of the abnormal biochemical findings. In the seventh severely oedematous patient combined albumin and diuretic therapy led to a loss of $27 \mathrm{~kg}$ in 14 days.

\section{Introduction}

The management of severe nephrotic syndrome is based largely on diet and diuretics, though specific therapy may be used in some forms of glomerulonephritis-for example, conticosteroids in minimal lesion glomerulonephritis. Occa-

Royal Infirmary, Edinburgh EH3 9YW

A. M. DAVISON, B.Sc., M.R.C.P., Registrar, Medical Renal Unit

A. T. LAMBIE, M.B., M.R.C.P., Consultant Physician, Medical Renal Unit A. H. VERTH, Technical Officer, Medical Renal Unit

A. H. CASH, PH.D., F.R.C.P., Deputy Director, Regional Blood Transfusion Centre

sional reponts have mentioned the use of plasma volume expanders. Janeway et al. (1944) undertook the first study of human albumin in this context and concluded that at least in the adult nephrotic patient it had no place; this conclusion was supported by Leutscher et al. (1949). Recent reponts, in which the importance of modern, powerful diuretics have been stressed, have included reference to the occasional use of human albumin (Chamberlain et al., 1966; Garnett and Webber, 1967; Silverberg and Kjellstrand, 1968; Snashall, 1971) but contain little evidence that the introduction of albumin was really necessary or that it was specifically instrumental in inducing a diuresis.

The proposed increase in the national capacity for plasma fractionation (Watt et al., 1972) brings with it the need to consider which patients are likely to benefit from such produots as salt-poor albumin. At the same time there is also a need for data on which to base detailed long-term planning of the national blood resources. We present here the results of a preliminary study to show the existence of a diureticresistant nephrotic syndrome and assess the role of intravenous human albumin in the management of such a condition.

\section{Patients and Methods}

To obtain some idea of the number of patients who might benefit from albumin infusions physicians were invited to refer patients who had oedema resistant to conventional diuretic therapy. In the succeeding 12 months out of a population of $1 \frac{1}{4}$ million 12 patients with the nephrotic syndrome were submitted for possible albumin therapy (table I). A funther patient, admitted for an appendicectomy, was subsequently treated for the nephrotic syndrome.

All patients received a diet containing $22 \mathrm{mEq}$ of sodium 